\title{
Characteristics of Hypertension Patients in Coastal District Percut Sei Tuan
}

\author{
${ }^{1}$ Zuhrina Aidha, ${ }^{1}$ Reni Agustina Harahap, ${ }^{1}$ Delfriana Ayu A.
}

\author{
${ }^{1}$ Faculty of Public Health, UIN Sumatera Utara, Medan, Indonesia \\ Coresponding author: Zuhrina Aidha, e-mail: zuhrinaaidha@uinsu.ac.id \\ Co-author : RAH: reniagustinah@gmail.com, DAA: delfriana@gmail.com
}

Submitted:20/08/2020 Revised:02/09/2020 Accepted:19/10/2020 Published online: 21/10/2020

doi: https://doi.org/10.35308/j-kesmas.v7i2.1673 How to cite this article: Aidha, Z., Harahap, R. A.,\& A., Ayu. D. (2020).

Characteristics of Hypertension Patients in Coastal District Percut Sei Tuan. J-Kesmas: Jurnal Fakultas Kesehatan Masyarakat (The Indonesian Journal of Public Health), 7(2), 117-122.

\begin{abstract}
Hypertension is a non-communicable disease that is a threat to people in developing countries. Hypertension is also called the silent killer which is the cause of death in Indonesia. The prevalence of hypertension in North Sumatra Province reaches $6.7 \%$ of the population in North Sumatra, based on data from the Ministry of Health's Health Research and Development Agency. This means that the population of North Sumatra suffering from hypertension reaches 12.42 million people spread across several districts (Ministry of Health, 2013). aro Regency is one of the highest numbers of hypertension, following Deli Serdang district. In 2016 the number of hypertensive patients in Karo Regency was 12,608 people, this prevalence was higher in female sex (52\%) men (48\%), the largest in the age group 55-59 years (Simbolon, 2016). This type of research is descriptive using the quantitative method with a cross sectional approach. Determination of the number of samples by simple random sampling, and obtained a sample of 30 people. Data analysis using univariate analysis to see the frequency distribution of each variable. The results of this study found that, 50\% of respondents had high school education, $85 \%$ of respondents as housewives, respondents aged between 40-60 years, and 60\% of respondents had a family history of hypertension.
\end{abstract}

Keywords: Hypertension, Family History, Characteristics, Health, Coastal District.

\section{Introduction}

The pattern of the spread of the disease has undergone changes from infectious diseases (infectious) to non-infectious diseases (not contagious). Non-communicable diseases, such as hypertension, pose a threat to people in developing countries. Hypertension is the cause of death, called the silent killer. This disease is a challenge to health problems globally because of the high prevalence of cardiovascular disease and chronic kidney disease (Mills et al., 2016). The World Health Organization (WHO) released, hypertension is often the cause of undiagnosed death. Patients with hypertension who are undiagnosed, not receiving treatment so that they cannot control blood pressure in the long run result in complications of hypertension, increased cardiovascular disease (WHO, 2013).

Hypertension is defined as an increase in systolic blood pressure of at least $140 \mathrm{mmHg}$ or diastolic blood pressure of at least $90 \mathrm{mmHg}$. Hypertension travel very slowly even people with hypertension may not show symptoms for years. When symptoms occur, they are usually non-specific, such as headaches or dizziness. The cause of hypertension is unknown in $95 \%$ of cases and about
$5 \%$ of hypertension occurs secondary to other disease processes, such as renal parenchymal disease or primary aldosteronism. From several other studies it was also reported that uncontrolled hypertension can cause a 7 times greater chance of stroke, 6 times more likely to have congestive heart failure, and 3 times greater heart attack.

The results of the study indicate that the age of hypertensive patients is in the final age group of 16 respondents $(30.2 \%)$. The sex of the patients is mostly women as many as 30 respondents $(56.6 \%)$. patients did not adhere to taking medication as many as 43 respondents $(81.1 \%)$. patients not obese were 32 respondents $(60.4 \%)$. Most patients did not have a family with a history of hypertension as many as 29 respondents $(54.7 \%)$. patients did not have smoking habits as much as 32 respondents $(60.4 \%)$. The sports habits of most patients are irregular as many as 34 respondents $(64.2 \%)$. Blood pressure in hypertensive patients falls into the category of stage I hypertension as many as 28 respondents (52.8\%) (Azhar, 2017).

Hypertension often develops due to risk factors of unhealthy living habits, such as eating foods that are high in salt, consuming inadequate fruits, using alcohol, lacking physical activity and lack of exercise 
and stress. This habit is strongly influenced by the activities and living conditions of a person. The percentage of men to suffer from hypertension at the age of up to 45 years is higher than women. However, at the age of more than 45 years, the percentage of hypertension in men and women is almost the same. In women, who use oral contraception, especially in obese women and older women, have a risk of two to three times greater risk of suffering from hypertension than women who do not use it.

The prevalence of hypertension in North Sumatra Province reaches $6.7 \%$ of the population in North Sumatra, based on data from the Ministry of Health's Health Research and Development Agency. This means that the population of North Sumatra suffering from hypertension reaches 12.42 million people spread across several districts (Ministry of Health, 2013). Karo Regency is one of the highest numbers of hypertension, following Deli Serdang district. In 2016 the number of hypertensive patients in Karo Regency was 12,608 people, this prevalence was higher in female sex $(52 \%)$ men $(48 \%)$, the largest in the age group 55-59 years (Simbolon, 2016). According to Azhar (2017) in the results of his study, the characteristics of hypertensive patients in Gamping I Sleman Yogyakarta Public Health Center were included in the final age group, female, nonadherent, not obese, had no family with a history of hypertension, did not have smoking habits, irregular exercise habits, and having blood pressure fall into the category of stage I hypertension.

Data from the North Sumatra Provincial Health Office recorded 50,162 people suffering from hypertension. The data, recorded the most suffer from hypertension are women with a total of 27,021 . The age that suffered the most was the age above 55 years with the number of 22,618 and then ages 18 to 44 years with the number 14,984 and ages 45 to 55 years with the number 12,560. In 2015, there were recorded hypertension sufferers in North Sumatra in JanuaryOctober 2015, reaching 15,199. Most sufferers were women with a number of 87774 . The age of the most patients was seen in the data also aged above 55 years with the number 85254 , followed by ages 45 to 55 years with the number 44909 and ages 18 to 44 years with the number 21776 (Sumut Pos, 2016) .

Hypertension is the main cause of death which triggers various complications including stroke, death of heart muscle tissue and failure of kidney function. The trigger factors for hypertension can be distinguished by those who cannot be controlled (such as heredity, gender, and age) and who can be controlled (such as obesity, lack of exercise, smoking, and consumption of alcohol and salt), (Sigarlaki, 2006). Hypertension has various risk factors that are closely related to the triggers of the disease. Various risk factors for hypertension include genetic, race, age, sex, smoking, obesity, as well as psychological stress and factors that cause recurrence of hypertension, including diet, smoking and stress (Yogiantoro, 2006 \& Marliani, 2007). Risk factors for hypertension in Indonesia are age, low education, smoking habits, consuming caffeinated drinks> 1 time per day, alcohol consumption, lack of physical activity, obesity and abdominal obesity (Rahajeng, 2009).

People in Indonesia own awareness and knowledge about hypertension is still very low, so family support for family members of hypertensive patients is also low. It is proven that people prefer ready-to-eat foods which are generally low in fiber, high in fat, high in sugar and contain a lot of salt. This unhealthy diet is a trigger for hypertension (Dinkes, 2008).

Factors that influence hypertension are divided into modifiable factors (diet, smoking, physical activity, alcohol consumption, high salt meal), and non-modifiable factors (age, sex, family history and ethnicity).

Septiawan(2018) mention that at age, 30-50 years old idiopathic hypertension will appear and will increase with age (Kishore et al., 2016). In gender factors, women are more easily attacked by hypertension than men (Venkataraman et al., 2013). In the factor of family history with hypertension, someone with parents who suffer from hypertension is more at risk for hypertension. Genetic factors play a role in the occurrence of hypertension (Matar et al., 2015). Genetic factors are associated with an increase in the amount of intracellular sodium and a decrease in the ratio of potassium and sodium. In Ethnic factors, the incidence of hypertension is greater among black ethnicities than whites, the exact cause is still unclear but can be associated with lower renin levels, greater sensitivity to vasopressin, higher salt intakes and greater environmental stress (Bell et al. 2015).

Herawati research (2011) states that more than half $(56.4 \%)$ of hypertensive sufferers have poor dietary patterns. Most (80.8\%) people with hypertension have poor exercise habits. Most $(82.1 \%)$ patients with hypertension have uncontrolled blood pressure. There is a significant relationship between dietary patterns and controlled blood pressure in patients with hypertension. There is a 
significant relationship between exercise habits and controlled blood pressure in patients with hypertension.

The initial survey in the coastal area of Percut Sei Tuan Subdistrict, Deli Serdang Regency, in November 2017 for 30 female respondents, obtained data of $60 \%$ suffering from hypertension, consumption of high-salt foods and no regular exercise activities. The low education of coastal communities is thought to cause high prevalence of hypertension in Percut Sei Tuan Subdistrict. Based on these data, it is necessary to conduct research to obtain characteristics of hypertensive patients in the Percut community.

\section{Materials and Methods}

This study uses a survey method with a descriptive approach. The study was conducted from January to April 2019. The instrument used was a questionnaire sheet which included questions about age, sex, occupation, education and family history with hypertension. Research activities began since taking care of research permits, initial surveys, approval of proposals by research institutions, measurement of pre-intervention, implementation of interventions, analysis of data to compile research reports. The sampling technique was taken using simple random sampling. Samples are taken randomly, regardless of the level in the population, each element of the population has the same opportunity and is known to be selected as the subject. Obtained a sample of 30 peoples.

\section{Results}

\section{Frequency Distribution of Hypertension in Sub-District Coastal Communities Whip Sei Tuan}

Blood pressure in this study was grouped into three groups: low, normal, and high blood pressure. The results of the study were 5 respondents with low blood pressure, 9 people with normal blood pressure, and 19 respondents suffering from high blood pressure.

Table 1. Blood Pressure Frequency Table

\begin{tabular}{cccccc}
\hline & Frequency & Percent & $\begin{array}{c}\text { Valid } \\
\text { Percent }\end{array}$ & $\begin{array}{c}\text { Cumulative } \\
\text { Percent }\end{array}$ \\
\hline \multirow{4}{*}{ Pretest } & Low & 5 & 16.7 & 16.7 & 16.7 \\
& Normal & 9 & 30.0 & 30.0 & 46.7 \\
& Height & 16 & 53.3 & 53.3 & 100.0 \\
& Total & 30 & 100.0 & 100.0 & \\
\hline
\end{tabular}

\section{Characteristics of Respondents by Education Level}

Education has an important role in people's lives because the level of education becomes one measure of the progress of the community so that the higher the level of education of a society, the more civilization will develop and the development of living standards and lifestyles. Besides that education also has an important role in the process of empowering reliable human resources (HR), because with reliable HR, the development process will be more able to run well and smoothly. In general, it can be said that the community of Percut Sei Tuan Subdistrict is included in the community that has advanced in the field of education, this is evidenced by the average member of the community having taken formal education of various levels of education, be it elementary, junior high, upper secondary or even also has arrived at higher education both at the undergraduate level one degree (S1) and many people have started interest in continuing their education to
Post Graduate (S2), this is marked by the level of education with Tk to college facilities.

As many as 30 respondents were surveyed, $50 \%$ (30) of the last education respondents were at the level of High School (SMA) and Higher Education (PT), the rest were respondents with the latest education at the level of Elementary School (SD) and First Middle School (SMP).

\section{Characteristics of Job-Based Respondents (Livelihoods)}

Society and economy are like two sides of a coin that cannot be separated, meaning that society and economy will always be related, this is because prosperity or the decline of a society can be measured, one of them is in terms of the economic level and the people are economic actors. if the community does not exist. The level of the economy of many people is determined in terms of business or livelihood, the more advanced the business, the more prosperous the businessmen will be. 
Information obtained from respondents surveyed, as many as $20(66.7 \%)$ respondents chose the "Other" option on the questionnaire which showed they were housewives. After further interviews, information was obtained from 20 respondents that their husbands worked as fishermen. The rest, as many as $15(16.6 \%)$ respondents as private employees, as many as $13.3 \%$ (4) respondents had an entrepreneurial livelihood, and 1 (3.3\%) of respondents were retirees.

\section{Characteristics of Respondents by Age}

According to the age group of Percut villagers, the age group above 30 years is more dominant, namely 1,374 people, while the age of 20-30 is 808 people, and the rest are under the age group of 20 years. This study classifies age into the age group $<50$ years, $50-60$ years, and $>60$ years. The reason for grouping at that age is because this study was carried out in the elderly or over 50 years.

Information obtained in the study, as many as 9 people $(30 \%)$ respondents were in the age group 50-60 years, 5 people (16.7\%) respondents were aged $>60$ years, and 16 people $(53.3 \%)$ respondents aged $<50$ years, and after the next interview is at the age of 47-49 years.

\section{Characteristics of Respondents Based on Family History}

According to the family history of the respondents as many as 19 people (63.3\%) respondents who suffer from hypertension have a family history who also suffer from hypertension. The remaining 11 people (36.7\%) respondents who suffer from hypertension do not have a family history of hypertension.

\section{Discussion}

The coastal area is a transitional area of the sea and land. This condition causes coastal areas to get pressure from various activities and phenomena that occur on land and at sea. Phenomena that occur on land include abrasion, flooding and activities carried out by the community, namely the construction of settlements, forest clearing for rice fields, the construction of ponds and as an eventual impact on the coastal ecosystem. Similarly, phenomena in the ocean such as tides, storm waves and so on (Hastuti, 2012).

In addition to environmental problems health problems also occur in coastal areas. The most common diseases are skin diseases, diarrhea and hypertension. Based on the National Riskesdas in
2007, hypertension was ranked third in all causes of death, after stroke and $\mathrm{TB}$, with a proportion of deaths of $6.8 \%$. The national prevalence of hypertension in residents aged $>18$ years is $31.7 \%$. With the highest prevalence of hypertension in the Natuna Islands (coastal area) as much as $53.3 \%$ while the lowest prevalence in the Jayawijaya Mountains is $6.8 \%$. This is partly related to the presence of a diet, especially sodium intake which supports the risk of hypertension (Riskesdas, 2007).

According to Minister of Health, health risks always follow every movement of fishermen in an effort to fulfill their needs. Citing data from the Ministry of Health (2006) research on diseases and accidents that occur in traditional fishermen and divers, mentioning that a number of fishermen on Bungin Island, West Nusa Tenggara suffer from joint pain $(57.5 \%)$ and mild to deaf hearing loss $(11,3 \%)$. Whereas, fishermen in the Thousand Islands, DKI Jakarta, experienced barotrauma cases $(41.37 \%)$ and decompression abnormalities (6.91\%).

Based on the results of the study, some respondents had final education equivalent to elementary and junior high school. Education is one of the factors that influence a person's behavior. Including behaviors to prevent disease and improve public health. According to Lawrence Green's theory in the book introducing public health science by Cecep Triwibowo (2015) that changes in a person's behavior are determined by three factors, namely (1) predisposing factors, (2) supporting factors, and (3) driving factors.

Age is a risk factor for hypertension that cannot be changed. Therefore, as we get older, the prevalence of hypertension increases. This is also due to increasing age, decreases in body functions, especially blood vessel elasticity and heart performance. Recalling the notion of degenerative diseases is a disease that occurs due to decreased bodily functions. And hypertension is a type of degenerative disease.

This study divided into three categories of advanced age, namely $<50$ years, 50-60 years, and $>$ 60 years. It was found that the prevalence of hypertension from each age category was 16, 5 and 9 people. That is, the prevalence of high hypertension in the elderly. In line with the results of research conducted by Dedullah, that respondents with age categories $\geq 43$ years experienced hypertension as much as $50(33.3 \%)$ compared to the age group $\leq 43$ years in the community of Small Montoboi Subdistrict. Age categories $\geq 43$ years have a risk of 5.263 times greater suffering from hypertension 
compared to the age category $\leq 43$ years. With the same age group, Raihan's research also obtained significant results on the relationship between age and the prevalence of hypertension.

The research conducted by Gerungan, A et al. (2016) found that there was a significant relationship between age and the incidence of hypertension, age $\geq$ 40 years had the risk of hypertension by 11.71 times compared to age $<40$ years. In addition, research in the Thai region shows the relationship between age and hypertension and people aged $>40$ years have a risk of 4.2 times having hypertension compared to those aged less than 40 years. This right occurs because the increasing age the elasticity of blood vessels will decrease causing the blood flow to the body less so that the heart must work hard to fill the bloodstream so that it affects hypertension (Journal Medicine, 2015) (Ratna Ningsih).

Research Scholars (2018) states that the majority of respondents who suffer from hypertension have a family history of suffering from hypertension. It is stated that in $70-80 \%$ of cases of essential hypertension, there is a history of hypertension in the family. If a history of hypertension is found in both parents, then the suspicion of essential hypertension is greater. Hypertension is also often found in patients with monozygotic twins (one egg) if one of them suffers from hypertension. This guess supports that genetic factors have a role in the occurrence of hypertension.

\section{Conclusion}

The conclusion of this research are Prevalence of hypertension in the high coastal area of Percu Sei Tuan, than The respondent's last education is the majority of primary schools. Also The work of the majority respondents. Age of respondents ranged from 40-60 years. And Most of the respondents have a family history of hypertension.

\section{Acknowledgement}

Thank you to participants in Coastal District Percut Sei Tuan which helped in completing this research.

\section{Author Contribution and Competing Interest}

All of the authors contributed in collecting and analyzing the data, including preparing the manuscript. The author assures thet there is no conflict of interest in the activities and preparation of this report.

\section{Publisher's Note}

J-Kesmas: JurnalFakultas Kesehatan Masyarakat (Indonesia Journal of Public Health) remains neutral with regard to jurisdictional claims in published institutional affiliation.

\section{References}

Azhar, I. (2017). Gambaran karakteristik pasien hipertensi di Puskesmas Gamping I Sleman Yogyakarta. Tesis, Stikes Jenderal Achmad Yani Yogyakarta.

Herwati \& Sartika, W. (2014). Terkontrolnya Tekanan Darah Penderita Hipertensi Berdasarkan Pola Diet dan Kebiasaan Oleh Raga di Padang Tahun 2011. Jurnal Kesehatan Masyarakat, 8(1), 8-11.

Kishore, J., Gupta, N., Kohli, C. \& Kumar, N. (2016). Prevalence of Hypertension and Determination od Its Risk Factors in Rural Delhi. International Journal of Hypertension, 2016(ID 7962595), 1-7.

Mills, K. T., Bundy, J. D., Kelly, T. N., Reed, J. E., Kearney, P. M., Reynolds, K., \& He, J. (2016). Global Disparitas of hypertension Prevalence and Control; A Systematic Analysis of Populastion- Based Studies from 90 Countries. Circulation, 134(6), 441-450.

Noor, J. D. S. M. (2013). Metodologi Penelitian. Jakarta: Kencana Prenada Media Group.

Nugraha, B. (2013). Hubungan Tingkat Pengetahuan Keluarga Dengan Sikap Pencegahan Komplikasi Pada Pasien Hipertensi Di Wilayah Kerja Puskesmas Sangkrah Surakarta. Skripsi Universitas Muhammadiyah Surakarta.

Pangestu, A. A. (2016). Efektifitas Rebusan Buah Pepaya Mengkal dan Buah Mahkota Dewa Terhadap Perubahan Tekanan Darah Tinggi pada HIpertensi di Wilayah Kerja Puskesmas Kedungbanteng. Skripsi Universitas Muhammadiyah Purwokerto.

Pos, S., (2016). Sumut Pos. [Online] Available at: http://sumutpos.co/2016/11/15/penderitahipertensi-di-sumut-mencapai-50-ribu-lebih/ [Accessed 22 Desember 2017]. 
Prasetyorini, H. T., \& Prawesti, D. (2012). Stres pada penyakit terhadap kejadian komplikasi hipertensi pada pasien hipertensi. Jurnal Stikes, 5(1), 61-70.

Putra, A. M. P. \& Ulfah, A., (2016). Analisis faktor Risiko Hipertensi di Puskesmas Kelayan Timur Kota Banjarmasin. Jurnal Ilmiah Ibnu Sina, 1(2), $256-264$.

Republik Indonesia, K. K. (2014). Data Propinsi Sumatera Utara Riset Kesehatan Dasar Balitbangkes, Jakarta: Kementerian Kesehatan Republik Indonesia.

Riyanto, A., (2010). Basic Data Analysis for Helath Research Training. Pengolahan dan Analisis data Kesehatan.. Medan: Sekolah Tinggi Ilmu Kesehatan Rumah Sakit Haji Medan.

Septiawan, T., Permana, I., \& Yuniarti, F. A. (2018). Studi deskriptif karakteristik pasien hipertensi di wilayah kerja puskesmas gamping ii yogyakarta. Prosiding Konferensi Nasional Ke-7 Asosiasi Program Pascasarjana Perguruan Tinggi Muhammadiyah 'Aisyiyah (APPPTMA).

Simbolon, C. A., (2016). Prevalensi penderita Hipertensi pada Lansia di Kabupaten Karo Tahun 2016. Tesis Universitas Smatera Utara.

WHO, (2013). A Global Brief on Hypertension: Silent Killer, Switzerland: World Health Organization. 